\title{
Integrated crop-livestock versus conventional systems: use of soil indicators to detect short-term changes during seasonal variation
}

\author{
Nayane Jaqueline Costa Maia1,* (iD, Mara Cristina Pessôa da Cruz ${ }^{1}$ (D), José Carlos Batista Dubeux \\ Junior $^{2}$ (D), Leonardo Sartori Menegatto ${ }^{3}$ (D) Jeferson Garcia Augusto 3 (D), Gabriela Geraldi \\ Mendonça ${ }^{4}$ (D), Maira Caroline Terçariol ${ }^{1}$ (D), Joyce Graziella Oliveira ${ }^{3}$ (D), Flávia Fernanda Simili ${ }^{3}$ (iD \\ 1. Universidade Estadual Paulista "Júlio de Mesquita Filho" - Faculdade de Ciências Agrárias e Veterinárias - Jaboticabal (SP), Brazil. \\ 2. University of Florida - Institute of Food and Agricultural Sciences - North Florida Research and Education Center - Marianna (FL), United \\ States of America. \\ 3. Instituto de Zootecnia - Centro de Pesquisa de Bovinos de Corte - Sertãozinho (SP), Brazil. \\ 4. Universidade de São Paulo - Faculdade de Medicina Veterinária e Zootecnia - Pirassununga (SP), Brazil.
}

Received: Apr. 30, 2021 | Accepted: Sep. 13, 2021

Section Editor: Hector Velenzuela

*Corresponding author: nayane.maia1@gmail.com

How to cite: Maia, N. J. C., Cruz, M. C.P., Dubeux Junior, J. C. B., Menegatto. L. S., Augusto, J. G., Mendonça, G. G., Terçariol, M. C., Oliveira, J. G. and Simili F. F. (2021). Integrated crop-livestock versus conventional systems: use of soil indicators to detect short-term changes during seasonal variation. Bragantia, 80, e5821. https://doi.org/10.1590/1678-4499.20210127

\begin{abstract}
Soil quality indicators may have different seasonal trends during the year. The hypothesis of this study was that sowing maize and marandu palisadegrass with the presence of grazing animals might cause short-term changes in soil indicator responses. We compared four intercropping techniques: ICLS-1: maize plus marandu palisadegrass sown simultaneously, without herbicide; ICLS-2: maize plus marandu palisadegrass sown simultaneously, with herbicide; ICLS-3: maize plus marandu palisadegrass in lagged sowing (i.e., marandu palisadegrass sown 20 days after maize sowing); ICLS-4: maize plus marandu palisadegrass sown simultaneously (palisadegrass on the rows and inter-rows, with herbicide). Two control treatments in monoculture (i.e., grass and maize monocultures) represented the conventional systems. The soil was sampled three times over a one-year period, for the evaluation of carbon and nitrogen fractions as affected by seasonal variability. Results indicated that ICLS-1 and ICLS-4 enhanced soil quality more quickly during the seasonal variation. The ICLS-2 negatively affected microbial biomass (22\%), resulting in reduced labile carbon (43\%), carbon management index (33\%), and potentially mineralizable nitrogen (20\%). Labile carbon and the carbon management index were more sensitive and efficient indicators for verifying soil quality changes in the short-term. Results indicated that there is large variability in these soil indicators during the annual cycle, and further studies are needed to verify the effects of the tested systems on different soil nitrogen fractions and how they affect available nitrogen in the short-term. However, potentially mineralizable nitrogen can provide positive insights for short-term changes in the soil.
\end{abstract}

Key words: organic carbon, organic nitrogen, potentially mineralizable nitrogen, Zea mays L., Brachiaria brizantha cv. marandu.

\section{INTRODUCTION}

Soil quality can be affected by sowing method, vegetation cover, and performance of integrated crops (Silva et al. 2014). Studies have shown that intercropping cereal grains and grasses in the implementation of integrated crop-livestock systems (ICLS) has provided improvements in soil quality compared to conventional systems (Coser et al. 2016; Viaud et al. 2018). In general, the intercrop is established with simultaneous sowing of corn plus grass, and the forage grass seed is mixed with the fertilizer (Kluthcouski and Adair 2003; Mateus et al. 2007). In some cases, it is necessary to apply underdosing of herbicides such as nicosulfuron to reduce the competition of forage with corn, so that there is no loss in grain production (Jakelaitis et al. 2005; Freitas et al. 2008). 
Thus, these crop interactions above the ground might result in direct or indirect effects in several attributes of soil fertility (Loss et al. 2013). However, the evaluation of these interactions is a challenge regarding the sustainability assessments of these systems (Rakkar et al. 2017), especially when there is cattle interacting with the cropping systems. The study of rapid methods to assess soil quality may provide a thorough evaluation of these systems with high sensitivity (Chi et al. 2017).

One of the most striking characteristics of ICLS is the oscillation of soil organic carbon (C) and soil organic nitrogen (N) during the rotation and seasonal variability, as they decrease during the annual cultivation phase and recover very fast during the perennial pasture phase (Galindo et al. 2020). Soil N mineralization forecasts are of particular interest in agricultural systems (Osterholz et al. 2017), because they can identify management practices that increase soil $\mathrm{N}$ cycling rates in the short term, as well as indicating systems that are more effective in increasing soil quality and improving environmental performance (Ghimire et al. 2019).

However, there is still much that is not understood about how different integrated system arrangements alter microbial communities and labile fractions involved in soil $\mathrm{N}$ cycling. Therefore, a soil assessment in areas with this system requires globalized and integrated approaches, considering all the organic inputs into the system and their functions in the soil (Dumont et al. 2013).

It is commonly accepted that the soil organic $\mathrm{C}$ and $\mathrm{N}$ reservoir is made up of a large reservoir that changes very slowly and of small reservoirs that change very rapidly (Fierer et al. 2009). However, it is believed that these small reservoirs are less protected and, therefore, less able to respond to changes in temperature, soil moisture, plant growth, and animal residues, all of which follow a seasonal pattern (Wuest 2014; Omer et al. 2018). Most previous studies examining seasonal trends have tended to measure respiration and microbial factors, while very few analyzed labile forms of $\mathrm{C}$ and $\mathrm{N}$ in the soil. Furthermore, soil systems or treatments may have different seasonal trends during the production cycle.

Although there are many studies on the benefits of ICLS on soil quality indicators, there is still limited information on how the consortium of maize and palisadegrass pastures in these systems might affect soil quality during the seasonal cycle. Thus, an unanswered question is if sowing strategy could provide better results for $\mathrm{C}$ and $\mathrm{N}$ indicators in the soil, or how these systems can improve soil quality compared with conventional ones of maize monocultures and pastures with respect to seasonal variation.

In this study, we investigated the effects of conventional systems with monocultures, as well as different sowing arrangements for the implementation of ICLS, on soil C and N indicators. The hypothesis of this study is that the sowing of maize and marandu palisadegrass with the presence of grazing animals might cause short-term changes in soil indicator responses. It is expected that, by increasing the soil quality, we can recommend the best arrangement of sowing and choose more sensitive and efficient indicators to facilitate the production processes of pastures in ICLS.

\section{MATERIAL AND METHODS}

\section{Site description}

The experiment was conducted between November 2015 and January 2018 at Centro de Pesquisa de Bovinos de Corte, Instituto de Zootecnia/Agência Paulista de Tecnologia dos Agronegócios (APTA)/Secretaria de Agricultura e Abastecimento

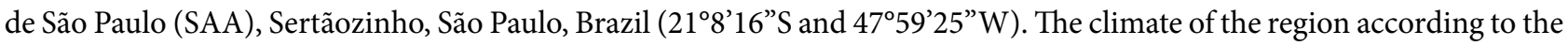
Köppen classification is Aw, characterized as humid tropical with a rainy season during summer and a dry season in winter. The study of soil quality indicators was performed between March 2017 and January 2018 (Fig. 1).

The soil of the experimental area is classified as clayey dystrophic red latosol (Santos et al. 2018), equivalent to an oxisol, according to the United States Department of Agriculture (USDA) soil classification (Bockheim et al. 2014). Before the implementation of this study, this area was managed for two consecutive years with corn to produce silage. Prior to this period, it was an area of extensive grazing system (livestock pasture using grass monoculture system) for 20 years. At the beginning of the experiment (November 2015), the soil had the attributes described in Table 1 . The methods of soil fertility used in these analyses are described in Raij et al. (2001). 


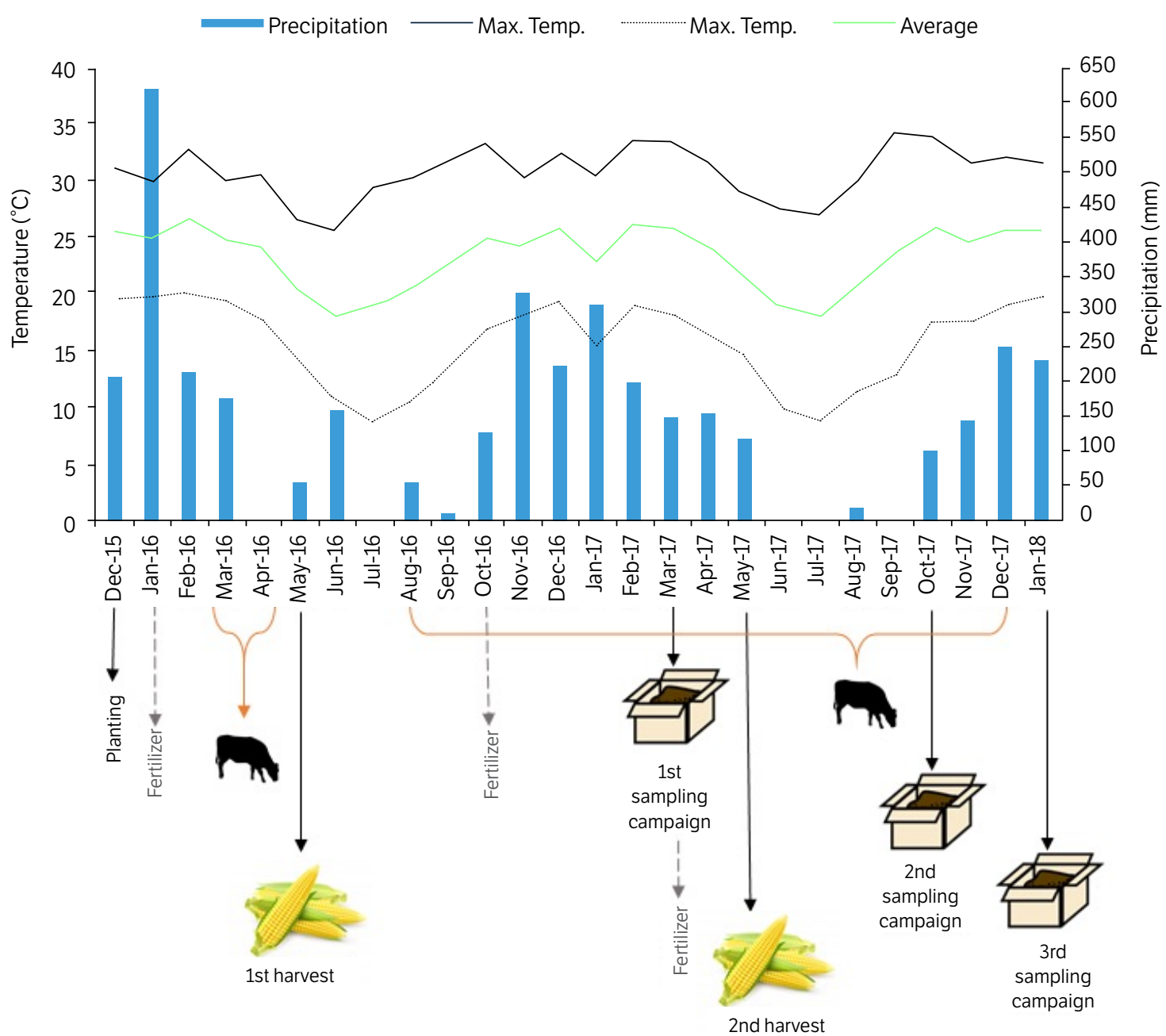

Temp: temperature.

Figure 1. Scheme of activities and weather data obtained from the meteorological station located at Centro de Pesquisa de Bovinos de Corte, Instituto de Zootecnia//Agência Paulista de Tecnologia dos Agronegócios (APTA)/Secretaria de Agricultura e Abastecimento de São Paulo (SAA), Sertãozinho, São Paulo, Brazil.

Table 1. Initial soil analysis of the experiment area.

\begin{tabular}{|c|c|c|c|c|c|c|c|}
\hline \multirow{2}{*}{ Depth } & \multirow{2}{*}{$\frac{P}{\mathrm{mg} \mathrm{dm}^{-3}}$} & \multirow{2}{*}{$\frac{O M}{\mathrm{~g} \mathrm{dm}^{-3}}$} & \multirow{2}{*}{$\begin{array}{c}\mathrm{pH} \\
\mathrm{CaCl}_{2}\end{array}$} & $\mathbf{K}$ & $\mathrm{Ca}$ & Mg & Total acidity \\
\hline & & & & \multicolumn{4}{|c|}{ - } \\
\hline $0-10 \mathrm{~cm}$ & 14 & 31 & 5.2 & 3.1 & 25 & 15 & 36 \\
\hline $10-20 \mathrm{~cm}$ & 9 & 30 & 4.9 & 1.8 & 19 & 12 & 45 \\
\hline
\end{tabular}

OM: organic matter; $\mathrm{pH}: 0.01$ mol. $\mathrm{L}^{-1}$ of a $\mathrm{CaCl}_{2}$ solution.

\section{Experimental design}

The experiment was carried out in a field of 16.02 ha divided into 18 paddocks of 0.89 ha each, organized in a randomized block design with six treatments and three replications. Treatments consisted of four intercropping sowing techniques between maize and marandu palisadegrass for the establishment of ICLS (ICLS-1, ICLS-2, ICLS-3, and ICLS-4), and two monoculture sowings (control treatments) representing the conventional systems: crop system (maize grain production, CS) and livestock system (beef cattle in grass monoculture pasture, LS). Sowing techniques took into consideration spatial 
arrangements (row or inter-row), grass sowing (simultaneous sowing or lagged sowing), and herbicide application (with and without). The four intercropping sowing techniques were:

- Maize plus marandu palisadegrass sown simultaneously, without herbicide (ICLS-1);

- Maize plus marandu palisadegrass sown simultaneously, with herbicide (ICLS-2);

- Maize plus marandu palisadegrass in lagged sowing (ICLS-3);

- Maize plus marandu palisadegrass sown simultaneously in maize rows and inter-rows, with herbicide (ICLS-4).

All treatments were sown in December 2015, using a no-till planter with five rows.

\section{Crop management}

In the CS, Pioneer P2830H maize (Zea mays L.) was sown with a 75-cm row spacing and a seed density of 70,000 plants.ha-1. At the time of sowing, $32 \mathrm{~kg}$.ha-1 of urea, $112 \mathrm{~kg}$.ha ${ }^{-1}$ of single superphosphate, and $64 \mathrm{~kg}$.ha-1 of potassium chloride were applied. In addition, $80 \mathrm{~kg} \cdot \mathrm{ha}^{-1}$ of urea, and $80 \mathrm{~kg} \cdot \mathrm{ha}^{-1}$ of potassium chloride were applied as side dress on the maize crop 20 days after sowing. Maize was planted for two consecutive years (December 2015 and December 2016), providing two harvests of maize grain (May 2016 and 2017) (Fig. 1). The field was left fallow between one harvest and the other.

In the LS, Urochloa brizantha (Hoechst. ex A. Rich.) R. D. Webster cv. marandu palisadegrass (syn. Brachiaria brizantha $\mathrm{cv}$. marandu) pasture was sown with a $37.5-\mathrm{cm}$ row spacing, with a seeding rate of $3.8 \mathrm{~kg}$.ha ${ }^{-1}$ of pure live seed. The marandu palisadegrass seeds were mixed with the sowing fertilizer: $32 \mathrm{~kg} \cdot \mathrm{ha}^{-1}$ of urea, $112 \mathrm{~kg} \cdot \mathrm{ha}^{-1}$ of single superphosphate, and $64 \mathrm{~kg} \cdot \mathrm{ha}^{-1}$ of potassium chloride. In addition, $40 \mathrm{~kg} \cdot \mathrm{ha}^{-1}$ of urea, $10 \mathrm{~kg} \cdot \mathrm{ha}^{-1}$ of single superphosphate, and $40 \mathrm{~kg} \cdot \mathrm{ha}^{-1}$ of potassium chloride were applied in the pasture in October 2016 and March 2017. Ninety days after sowing, the pasture was ready for grazing (March 2016). Three continuous stocking cycles were performed: the first cycle between March and April 2016 (30 days), the second between August and October 2016 (78 days), and the third between November 2016 and December 2017 (370 days).

In the ICLS, four types of intercropping of marandu palisadegrass and maize were studied. The same cultivar, row spacing, seeding rate, and fertilizers were performed as described for the CS, and the same seeding rate and fertilizers as described for the LS were used for all integrated systems. In ICLS-1, marandu palisadegrass was sown simultaneously with maize in the sowing row, resulting in a spacing of $75 \mathrm{~cm}$ between rows. In ICLS-2, simultaneous sowing was also performed equal

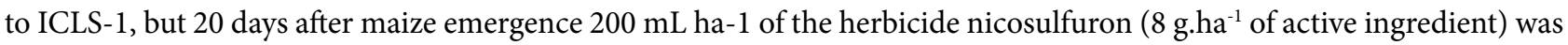
applied, using an agricultural sprayer machine. In ICLS-3, the marandu palisadegrass was sown 20 days after maize sowing (lagged sowing). For this purpose, the grass seed was mixed in the fertilizer with the second fertilization and inter-row sowing was performed using a minimum cultivator.

In ICLS-4, simultaneous sowing of marandu palisadegrass and maize was performed, but the grass seeds were sown within and between maize rows, resulting in a spacing of $37.5 \mathrm{~cm}$ between rows. In the ICLS- 4 system, the sowing fertilizer and the total amount of grass seed were divided among the maize intra- and inter-rows, aiming to provide a mixture of grass seeds and fertilizer. In addition, 200 mL.ha- ${ }^{-1}$ of the herbicide nicosulfuron ( $8 \mathrm{~g} \cdot \mathrm{ha}^{-1}$ of active ingredient) was applied 20 days after maize emerged. The underdose of the herbicide nicosulfuron applied in ICLS- 2 and ICLS- 4 was used to suppress the growth of marandu palisadegrass and to decrease competition with corn. The aim of this sub-dose technique was to improve grain productivity. The difference between ICLS-2 and ICLS-4 treatments was the space between rows in pasture planting.

In all integrated systems, the maize was harvested in May 2016 (Fig. 1). Ninety days after harvest, the pastures were ready for grazing. Two continuous stocking cycles were performed: the first cycle was between August and October 2016 (78 days), and the second cycle between November 2016 and December 2017 (370 days).

\section{Soil indicators and sampling}

Soil samplings were collected from 0-10 and 10-20 cm layers, in 10 subsamples per experimental plot. After sampling, the soils were transported to the soil fertility laboratory of the Universidade Estadual Paulista "Júlio de Mesquita Filho" (UNESP), School of Agricultural and Veterinarian Sciences, Jaboticabal city, Brazil. 


\section{Carbon indicators}

The $\mathrm{C}$ in the soil microbial biomass (MBC) was determined by irradiation in a microwave oven for $2 \mathrm{~min}$ (Monz et al. 1991). Subsequently, irradiated and non-irradiated samples were extracted with a K2SO4 solution ( $0.5 \mathrm{~mol}^{-1} \mathrm{~L}^{-1}$ ) (Silva et al. 2007). From the extract, $8 \mathrm{~mL}$ were used to determine the microbial biomass of the soil, by means of humid combustion (Walkley et al. 1934), with adaptations suggested by Raij et al. (2001).

The total organic carbon (TOC) was determined according to the method outlined by Walkley et al. (1934). The oxidized $\mathrm{C}$ was determined using the method described by Weil et al. (2003). From both the oxidized labile C by permanganate (LC) and the TOC in the soil, it was possible to calculate the carbon management index (CMI) of the soil, according to Blair et al. (1995), as described in the Eqs. 1 to 4 :

$$
\begin{gathered}
\mathrm{CMI}=\mathrm{CPI} \times \mathrm{LI} \times 100 \\
\mathrm{CPI}=\mathrm{TOC}_{\text {system }} / \mathrm{TOC}_{\text {reference }} \\
\mathrm{L}=\mathrm{L}_{\text {system }} / \mathrm{L}_{\text {reference }} \\
\mathrm{LI}=\mathrm{C}_{\text {labile }} / \mathrm{C}_{\text {non-labile }}
\end{gathered}
$$

CMI: C management index; CPI: C pool index; LI: lability index; $\mathrm{TOC}_{\text {system }}$ : soil organic $\mathrm{C}$ in a certain treatment; $\mathrm{TOC}_{\text {reference: }}$ the soil organic $\mathrm{C}$ of the reference treatment (native forested area); $\mathrm{L}_{\text {system }}$ : lability $(\mathrm{L})$ of $\mathrm{C}$ in the soil in a certain treatment; $\mathrm{L}_{\text {reference }}$ : lability of $\mathrm{C}$ in the reference treatment; $\mathrm{C}_{\text {labile: }}$ : concentration of labile $\mathrm{C}$ in the soil of the treatment; $\mathrm{C}_{\text {non-labile }}$ : concentration of non-labile $\mathrm{C}$ in the soil of the treatment.

The reference treatment was a native forest area close to the treatment site (system). In this area, soil samples were collected at the same period and depths as in the treatment systems.

\section{Nitrogen indicators}

The $\mathrm{N}$ from the soil microbial biomass $(\mathrm{MBN})$ was determined by the irradiation method in a microwave oven for 2 min (Monz et al. 1991). Then, irradiated and non-irradiated samples were extracted with a K2SO4 solution (0.5 mol.L $\left.{ }^{-1}\right)$ (Silva et al. 2007). A 10-mL aliquot was taken from the extract for $\mathrm{N}$ determination, using the digestion-distillation-titration method, described and simplified by Silva et al. (2007).

The total organic nitrogen (TON) was measured by an adaptation of the method suggested by Raij et al. (2001). The potentially mineralizable nitrogen (PMN) was extracted by alkaline hydrolysis using the direct steam distillation method (DSD) (Roberts et al. 2009). In this case, the determination of $\mathrm{N}$ was made as described for TON.

\section{Statistical analysis}

Randomized blocks in a split-split-plot design were used. The model included the effect of blocks (three blocks), treatments (six systems), soil depth (two depths), and evaluation periods (three periods). The production systems were considered the main factor, while depth and sampling periods as secondary factors. The data were submitted to a variance analysis (ANOVA) and, when significant differences were found, an unfolding of the data was made, with means being compared by the Tukey's test $(\alpha=0.05)$.

Principal components analysis (PCA) was used as a dimensional reduction method to describe the relationship between all the soil indicators evaluated. The Kaiser criterion (1960) was used to choose the principal components that explained most of the variation in the data set. All statistical analyses were performed in Python 3.8 and Statistica 7 software. 


\section{RESULTS AND DISCUSSION}

\section{Carbon indicators assessing soil quality}

The different sowings of the ICLS had no significant difference in relation to CS and LS treatments, on the MBC and CMI (Fig. 2). However, the LS treatment obtained the least LC concentration, compared to the other systems evaluated (Fig. 2c). $\mathrm{MBC}$ was greater in the $0-10 \mathrm{~cm}$ layer (Table 2), and greater $\mathrm{C}$ contents of this microbial fraction were obtained in treatments CS, ICLS-1, and ICLS-4 (Fig. 2a). However, these treatments were only statistically significant, with respect to ICLS-2. In the seasonal variability studied, we found that $\mathrm{MBC}$ and $\mathrm{MBN}$ correlate approximately $60 \%$ with the concentration of total organic $\mathrm{C}$ pools and PMN in ICLS-1 (Table 3). These values suggest a greater increase of the microbial community in this treatment during the seasonal cycle, and with that a short-term increase of active $\mathrm{N}$ and C pools in the soil (Strickland et al. 2019).

Table 2. Carbon and nitrogen indicators of soil quality, as a function of soil depths and sampling periods (means $\pm S E M, n=108)^{*}$.

\begin{tabular}{|c|c|c|c|c|c|c|c|}
\hline \multirow[b]{2}{*}{ Depth } & \multicolumn{4}{|c|}{ Carbon } & \multicolumn{2}{|c|}{ Nitrogen } & \multirow{2}{*}{$\begin{array}{l}\text { Ratio } \\
\text { C/N } \\
\text { Soil }\end{array}$} \\
\hline & $\begin{array}{c}\text { Total organic } \\
\left(\mathbf{g} \cdot \mathbf{k g}^{-1}\right)\end{array}$ & $\begin{array}{l}\text { Microbial } \\
\text { biomass } \\
\left(\mathrm{mg}^{-k^{-1}}\right)\end{array}$ & $\begin{array}{l}\text { Labile } \\
\left(\mathrm{mg}^{\left.-\mathrm{kg}^{-1}\right)}\right.\end{array}$ & $\begin{array}{c}\text { Carbon } \\
\text { management } \\
\text { index }\end{array}$ & $\begin{array}{l}\text { total Organic } \\
\left(\mathrm{mg}^{\mathrm{kg}} \mathbf{}^{-1}\right)\end{array}$ & $\begin{array}{c}\text { Potentially } \\
\text { mineralizable } \\
\left(\mathrm{mg} \mathrm{kg}^{-1}\right)\end{array}$ & \\
\hline $0-10 \mathrm{~cm}$ & $20.73 a \pm 0.22$ & $29.86 a \pm 4.26$ & $729.7 a \pm 29.00$ & $66.01 a \pm 18.96$ & $2.44 a \pm 0.00$ & $177.22 a \pm 35.14$ & $15.28 a \pm 0.24$ \\
\hline $10-20 \mathrm{~cm}$ & $20.59 a \pm 0.11$ & $26.48 b \pm 4.72$ & $698.0 \mathrm{a} \pm 19.00$ & $64.54 a \pm 19.03$ & $2.36 a \pm 0.00$ & $179.92 a \pm 35.23$ & $14.63 a \pm 0.21$ \\
\hline $\mathrm{P}$ & 0.59 & 0.01 & 0.14 & 0.29 & 0.05 & 0.16 & 0.07 \\
\hline $\mathrm{CV}$ & 4.6 & 21.6 & 14.7 & 10.5 & 7.4 & 19.4 & 9.1 \\
\hline \multicolumn{8}{|l|}{ Period } \\
\hline Mar./2017 & $20.39 a \pm 0.13$ & $29.24 a \pm 5.61$ & $761.08 a \pm 19.0$ & $67.84 a \pm 18.57$ & $2.49 a \pm 0.00$ & $176.74 a b \pm 26.98$ & $15.58 a \pm 0.19$ \\
\hline Oct./2017 & $20.89 a \pm 0.25$ & $28.91 a \pm 3.55$ & $796.43 a \pm 21.0$ & $70.92 a \pm 16.79$ & $2.33 b \pm 0.00$ & $190.95 a \pm 29.26$ & $14.93 a \pm 0.18$ \\
\hline Jan./2018 & $20.72 a \pm 0.28$ & $26.35 a \pm 4.66$ & $584.13 b \pm 19.6$ & $57.06 b \pm 9.53$ & $2.38 a b \pm 0.00$ & $168.03 b \pm 26.87$ & $14.36 a \pm 0.13$ \\
\hline $\mathrm{P}$ & 0.12 & 0.10 & $<0.001$ & 0.0001 & 0.02 & $<0.001$ & 0.82 \\
\hline $\mathrm{CV}$ & 5.0 & 21.7 & 16.6 & 16.7 & 9.9 & 15.9 & 9.7 \\
\hline
\end{tabular}

*Means followed by similar letters column-wise were not statistically different according to the Tukey test at a $5 \%$ probability level; P: significance; CV: coefficient of variation; SEM: standard error of mean (Blair et al. 1995).

It is possible that the addition of the herbicide nicosulfuron in ICLS-2 acted by reducing the concentration of microbial biomass $C$ in the soil by 25\% (Karpouzas et al. 2014a; Karpouzas et al. 2014b). In the other treatments, such reduction was less than $10 \%$ (LS and ICLS-3). The proportion of MBC represents $17 \%$ of the LC and $23 \%$ of the total organic C pools of ICLS-4, while ICLS-2 represents a negative correlation of more than $40 \%$ in these indicators (Table 3), possibly caused by the addition of the herbicide. Even though the herbicide was also applied in ICLS-4, the sowing arrangement in rows and inter-rows may have mitigated the herbicide's effect on the soil microbial community, diluting damages in function of a greater spatial distribution of the grass. Moreover, even after the application of nicosulfuron, the presence of different species and the increase in plant density provided more sources of energy and $\mathrm{C}$ in the soil that may have mitigated the herbicide effects, due to the increase in soil coverage and the number of roots that help to increase the microbial biomass (Freitas et al. 2018).

Table 3. Correlation ( $r$ ) between LC, PMN, TOC, total organic N, and MBC and MBN in treatments.

\begin{tabular}{ccccccc}
\hline Treatments & LC/TOC & MBC/TOC & MBC/LC & PMN/TON & MBN/TON & MBN/PMN \\
\hline CS & 0.42 & 0.3 & -0.16 & -0.08 & 0.25 & 0.16 \\
\hline LS & 0.04 & 0.04 & -0.21 & 0.01 & 0.21 & 0.56 \\
\hline ICLS-1 & 0.21 & 0.65 & 0.09 & 0.18 & 0.33 & 0.62 \\
\hline ICLS-2 & -0.40 & -0.04 & -0.43 & 0.15 & 0.41 & 0.30 \\
\hline ICLS-3 & 0.15 & 0.28 & -0.05 & -0.30 & -0.60 & -0.23 \\
\hline ICLS-4 & 0.23 & -0.12 & 0.17 & 0.28 & 0.41 & 0.15 \\
\hline
\end{tabular}

LC: labile C; PMN: potentially mineralizable N; TOC: total organic C; TON: total organic N; MBC: microbial biomass C; MBN: microbial biomass N; CS: crop monoculture system; LS: livestock pasture monoculture system; ICLS-1: maize and marandu palisadegrass sown simultaneously, without herbicide; ICLS-2: maize and marandu palisadegrass sown simultaneously, with herbicide; ICLS-3: maize and marandu palisadegrass in lagged sowing; ICLS-4: maize and marandu palisadegrass sown simultaneously in maize rows and inter-rows, with herbicide. 

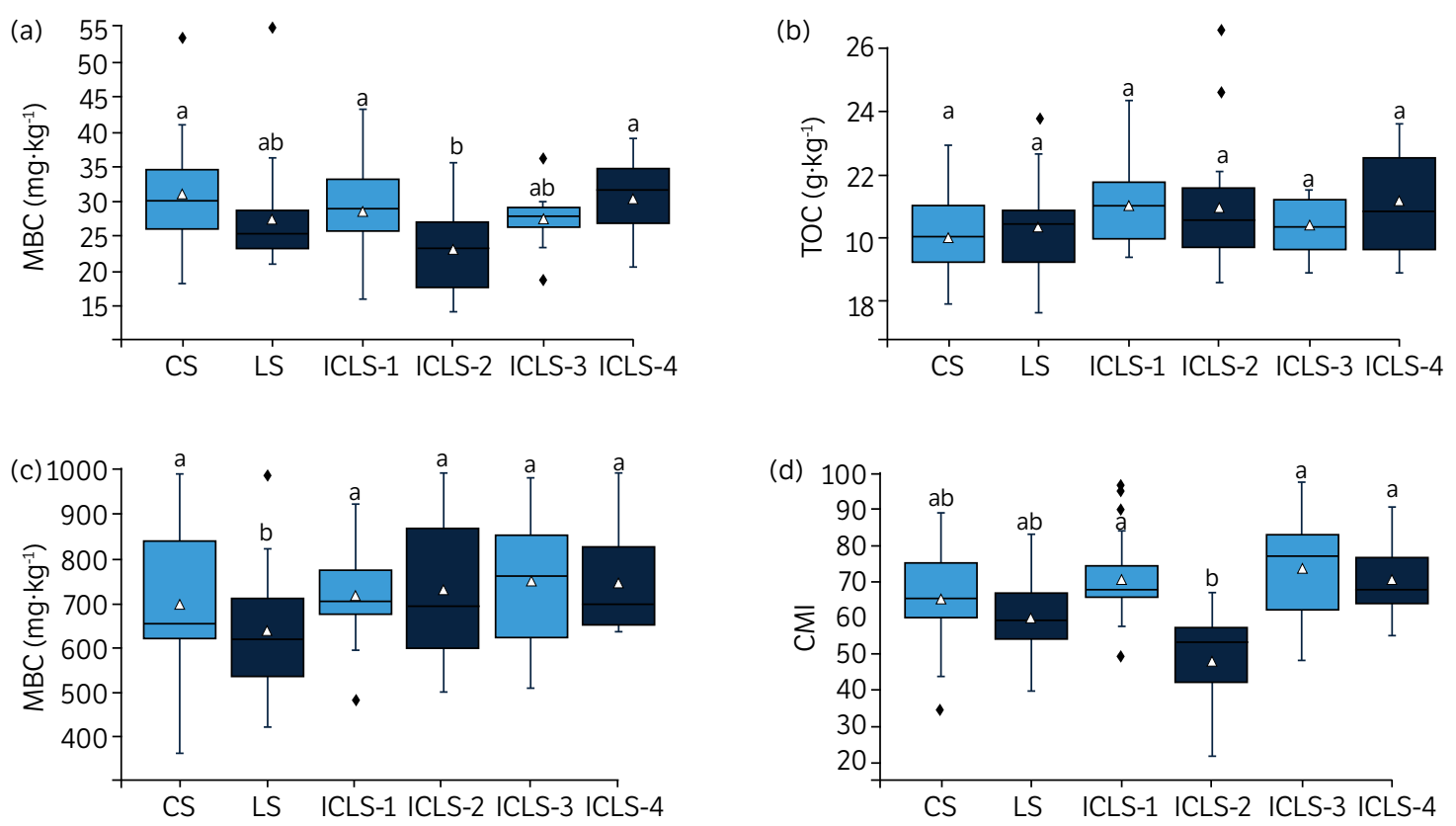

Figure 2. Soil carbon indicators to assess soil quality as a function of management system*.

MBC: soil microbial biomass carbon; TOC: total organic carbon; LC: labile carbon; CMI: carbon management index; CS: crop monoculture system; LS: livestock pasture monoculture system; ICLS-1: maize and marandu palisadegrass sown simultaneously, without herbicide; ICLS-2: maize and marandu palisadegrass sown simultaneously, with herbicide; ICLS-3: maize and marandu palisadegrass in lagged sowing; ICLS-4: maize and marandu palisadegrass sown simultaneously in maize rows and inter-rows, with herbicide; - (internal): the second quartile or median; : the first and third quartiles; $T$ and $\mathrm{I}$ : third and first quartiles up to the upper and lower limits; $\Delta$ : values of the means; maximum and minimum values; *means followed by similar letters do not differ according to the Tukey test at a $5 \%$ probability level.

The analysis of variance indicated significant effects on sampling period and systems for $\mathrm{C}$, but there was no interaction between them (Table 2). A lower concentration of LC was observed in LS, with a 15\% difference from other treatments (Fig. 2c). In comparison with TOC, the oxidized LC estimates a $\mathrm{C}$ pool that is more closely associated to the biological and labile functions of the soil, such as nutrient cycling (Duval et al. 2018). The CMI of the soil is dependent on the C existing in the microbial biomass (Fig. 2d), and thus in ICLS-2 the CMI was significantly reduced with the addition of the herbicide (33\% difference) in comparison to the other integrated systems (Fig. 2a), which confirms the high negative correlation value observed between these indicators (Table 3) (Duval et al. 2018; Bongiorno et al. 2019).

Studies comparing labile fractions of $\mathrm{C}$ between crop-livestock integrated systems and conventional systems found that the greater the input of residues in the soil, the greater the LC and the CMI are in ICLS treatments, regardless of grazing intensity (Loss et al. 2013). Areas with greater organic inputs are likely to be the ones that present greater efficiency of soil microbial biomass (SMB) (Ghimire et al. 2019).

Soil sampling dates affected the contents of LC and the CMI (Table 2). The concentrations of these indicators were lower in the soil sampled in January 2018 (Fig. 1), possibly because of greater rainfall during this month (144 mm). It is possible that the microbial populations and soil respiration were more active throughout this rainy period. Additionally, compounds containing LC of the soil organic matter can be mineralized more rapidly in the soil surface, in comparison to deeper layers, causing reduction in the LC by being more rapidly oxidized or converted into TOC in the soil (Wang et al. 2017).

\section{Nitrogen indicators to assess soil quality}

The principal effects of $\mathrm{N}$ indicators are presented in Table 2 and Fig. 3. Interactions were significant only for MBN, $\mathrm{C} / \mathrm{N}-\mathrm{SMB}$, and PMN/TON, which are presented in Table 4. The CS treatment resulted in less concentration of MBN in the soil, in comparison to the treatments with livestock, which differed among themselves (ICLS-3 and ICLS-4; Fig. 3c). Both treatments containing livestock were $30 \%$ more efficient in increasing $\mathrm{N}$ content in the MBN. Continuous supply of plant 
and animal residues to the soil might have affected these responses, improving survival and proliferation of microorganisms, leading to a consequent increase of the SMB (Rakkar et al. 2017; Duval et al. 2018).

Table 4. MBN as a function of soil depth and periods; $\mathrm{C} / \mathrm{N}-\mathrm{SMB}$ as a function of depth and periods; relationships between PMN and TON as a function of periods. Values are presented as mean*.

\begin{tabular}{|c|c|c|c|c|c|c|c|c|c|c|c|c|c|}
\hline \multirow{3}{*}{ Treatments } & \multicolumn{5}{|c|}{ MBN $\left(\mathbf{m g} \cdot \mathbf{k g}^{-1}\right)$} & \multicolumn{5}{|c|}{$\mathrm{C} / \mathrm{N}-\mathrm{SMB}$} & \multirow{2}{*}{\multicolumn{3}{|c|}{$\begin{array}{c}\text { PMN / TON } \\
\text { Period }\end{array}$}} \\
\hline & \multicolumn{3}{|c|}{ Period } & \multicolumn{2}{|c|}{ Depth } & \multicolumn{3}{|c|}{ Period } & \multicolumn{2}{|c|}{ Depth } & & & \\
\hline & Mar./17 & Oct./17 & Jan./18 & $\begin{array}{l}0-10 \\
\mathrm{~cm}\end{array}$ & $\begin{array}{c}10-20 \\
\mathrm{~cm}\end{array}$ & Mar./17 & Oct./17 & Jan./18 & $\begin{array}{l}0-10 \\
\mathrm{~cm}\end{array}$ & $\begin{array}{c}10-20 \\
\mathrm{~cm}\end{array}$ & Mar./17 & Oct./17 & Jan./18 \\
\hline $\mathrm{CS}$ & $\begin{array}{c}3.06 \\
c B\end{array}$ & $3.71 \mathrm{bB}$ & $\begin{array}{c}10.89 \\
\mathrm{aA}\end{array}$ & $\begin{array}{l}6.69 \\
a b A\end{array}$ & $\begin{array}{c}5.08 \\
b A\end{array}$ & $\begin{array}{c}12.17 \\
\mathrm{aA}\end{array}$ & $\begin{array}{c}10.93 \\
\mathrm{aA}\end{array}$ & $\begin{array}{c}2.90 \\
c B\end{array}$ & $\begin{array}{c}9.96 \\
\mathrm{aA}\end{array}$ & $\begin{array}{l}7.38 \\
a b B\end{array}$ & $\begin{array}{c}71.84 \\
a B\end{array}$ & $\begin{array}{c}94.18 \text { a } \\
A B\end{array}$ & $\begin{array}{c}108.80 \mathrm{ab} \\
\text { A }\end{array}$ \\
\hline LS & $\begin{array}{c}8.82 \\
b A\end{array}$ & $8.81 \mathrm{aA}$ & $3.48 \mathrm{cB}$ & $\begin{array}{c}9.20 \\
\mathrm{aA}\end{array}$ & $\begin{array}{l}4.87 \\
b B\end{array}$ & $\begin{array}{c}4.45 \\
b B\end{array}$ & $\begin{array}{l}3.35 \\
b B\end{array}$ & $\begin{array}{c}11.62 \\
\mathrm{aA}\end{array}$ & $\begin{array}{l}4.15 \\
b B\end{array}$ & $\begin{array}{c}8.80 \\
a A\end{array}$ & $\begin{array}{c}61.27 \\
a B\end{array}$ & $\begin{array}{c}\text { 65.07ab } \\
A B\end{array}$ & $\begin{array}{c}84.40 b c \\
A\end{array}$ \\
\hline ICLS-1 & $\begin{array}{c}8.26 \\
b A\end{array}$ & $\begin{array}{l}5.73 \\
a b A\end{array}$ & $\begin{array}{l}6.15 \\
b c A\end{array}$ & $\begin{array}{c}4.44 \\
b B\end{array}$ & $\begin{array}{c}8.99 \\
\mathrm{aA}\end{array}$ & $\begin{array}{c}3.20 \\
b B\end{array}$ & $\begin{array}{c}5.54 \\
\mathrm{bB}\end{array}$ & $\begin{array}{l}9.59 \\
a b A\end{array}$ & $\begin{array}{c}9.14 \\
\mathrm{aA}\end{array}$ & $\begin{array}{c}3.09 \\
c B\end{array}$ & $\begin{array}{c}65.70 \\
a B\end{array}$ & $\begin{array}{c}62.97 \\
\mathrm{bB}\end{array}$ & $\begin{array}{c}120.45 a \\
A\end{array}$ \\
\hline ICLS-2 & $7.86 \mathrm{bA}$ & $\begin{array}{l}6.59 \\
a b A\end{array}$ & $7.09 \mathrm{bA}$ & $\begin{array}{l}7.10 \\
a b A\end{array}$ & $\begin{array}{l}7.26 \\
a b A\end{array}$ & $3.57 \mathrm{bA}$ & $\begin{array}{c}3.64 \\
b A\end{array}$ & $4.52 \mathrm{cA}$ & $\begin{array}{c}3.46 \\
\mathrm{bA}\end{array}$ & $\begin{array}{l}4.36 \\
b c A\end{array}$ & $\begin{array}{c}75.19 \\
\mathrm{aA}\end{array}$ & $\begin{array}{c}73.80 \\
a b A\end{array}$ & $69.44 \mathrm{cA}$ \\
\hline ICLS-3 & $\begin{array}{c}12.98 \\
\mathrm{aA}\end{array}$ & $\begin{array}{l}6.77 \\
a b B\end{array}$ & $\begin{array}{l}5.72 \\
b c B\end{array}$ & $\begin{array}{l}6.88 \\
a b B\end{array}$ & $\begin{array}{c}10.10 \\
\mathrm{aA}\end{array}$ & $3.16 \mathrm{bA}$ & $\begin{array}{c}4.96 \\
b A\end{array}$ & $\begin{array}{l}5.15 \\
\text { bcA }\end{array}$ & $\begin{array}{c}4.40 \\
b A\end{array}$ & $\begin{array}{l}4.44 \\
\text { bcA }\end{array}$ & $\begin{array}{c}53.28 \\
a A\end{array}$ & $\begin{array}{c}63.89 \\
\mathrm{bA}\end{array}$ & $72.59 \mathrm{cA}$ \\
\hline ICLS-4 & $\begin{array}{c}9.08 \\
b A\end{array}$ & $8.93 \mathrm{aA}$ & $\begin{array}{l}8.07 \\
a b A\end{array}$ & $\begin{array}{c}6.97 \\
\mathrm{aA}\end{array}$ & $\begin{array}{r}7.71 \\
a b A\end{array}$ & $\begin{array}{c}3.48 \\
\mathrm{bA}\end{array}$ & 3.12 bA & $4.70 \mathrm{cA}$ & $\begin{array}{c}3.09 \\
b A\end{array}$ & $\begin{array}{l}4.44 \\
\text { bcA }\end{array}$ & $\begin{array}{c}64.94 \\
\mathrm{aA}\end{array}$ & $\begin{array}{c}66.55 \\
\text { abA }\end{array}$ & $72.60 \mathrm{cA}$ \\
\hline
\end{tabular}

*Means followed by a same lowercase letter in a column and uppercase letter in a row are statistically equal according to the Tukey test at a $5 \%$ probability level; MBN: microbial biomass nitrogen; $\mathrm{C} / \mathrm{N}-\mathrm{SMB}$ : $\mathrm{C} / \mathrm{N}$ ratio of the soil microbial biomass; $\mathrm{PMN}$ : potentially mineralizable N; TON: total organic $\mathrm{N}$; $\mathrm{CS}$ : crop monoculture system; LS: livestock pasture monoculture system; ICLS-1: maize and marandu palisadegrass sown simultaneously, without herbicide; ICLS-2: maize and marandu palisadegrass sown simultaneously, with herbicide; ICLS-3: maize and marandu palisadegrass in lagged sowing; ICLS-4: maize and marandu palisadegrass sown simultaneously in maize rows and inter-rows, with herbicide.

The plots with the CS showed the largest C/N-SMB. In contrast, the ICLS plots were not different from the plots that had animals grazing (LS; Fig. 3d). The presence of livestock in these treatments may have benefited soil quality, because the processes of $\mathrm{C}$ and $\mathrm{N}$ transformation in the soil may occur faster during the seasonal cycle by having a greater supply of organic $\mathrm{N}$ relative to organic C (Galindo et al. 2020).

The CS and ICLS-1 increased the PMN, while in the other systems this indicator was approximately $20 \%$ lower (Fig. 3e). These results indicate that among the studied sowing arrangements in ICLS, the treatment ICLS- 1 could recover a greatest share of $\mathrm{N}$ in short term. This likely occurred because the LC and PMN pools accounted for 21 and 18\%, respectively, of the total organic $\mathrm{C}$ and $\mathrm{N}$ pools of ICLS-1 (Table 3).

For the conditions of our study, we found that PMN correlates with MBN concentration. The ICLS-1 treatment had the greatest correlation value (62\%) between these indicators, followed by LS (56\%) (Table 3). These values suggest that MBN contributes significantly to PMN in these treatments, especially in ICLS-1. The greater proportion of active pools of $\mathrm{N}$ pools for TON suggests faster turnover of soil organic matter in CS and ICLS-1 than in the other treatments (Fig. 3f). These results can be confirmed with the increase in PMN/TON over the seasonal cycle of CS and ICLS-1, ranging from 71 to 108 and from 65 to 120 , respectively (Table 4). The observed correlation between organic inputs and PMN is further supported, because the faster turnover of organic residues may translate into greater short-term $\mathrm{N}$ availability during the seasonal cycle (Wuest 2014; Omer et al. 2018; Strickland et al. 2019). Using these ratios may be useful for assessing changes in soil quality during seasonal variability.

Throughout the experiment, LC contents were greater in soil samplings performed from October to March, which was reflected in an increased CMI during this period (Table 2). Treatments ICLS-1, ICLS-3 and ICLS-4 provided an increase in MBN, in the 10-20 cm depth. However, ICLS-4 was not statistically different from ICLS-2 at this depth (Table 4). Unlike conventional systems, this fraction of $\mathrm{N}$ in the crop-livestock integrating systems maintained the same concentration in the second sampled soil layer. This behavior indicates more benefits related to the crop consortium and to the introduction of livestock in the system. Nevertheless, long-term research is needed to explore these management strategies with ICLS and its potential to improve soil quality in the deeper soil layers below $20 \mathrm{~cm}$. 
(a)

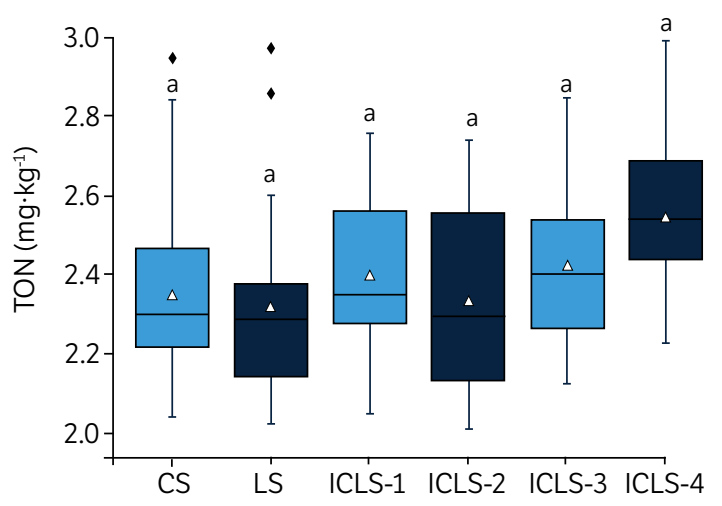

(c)

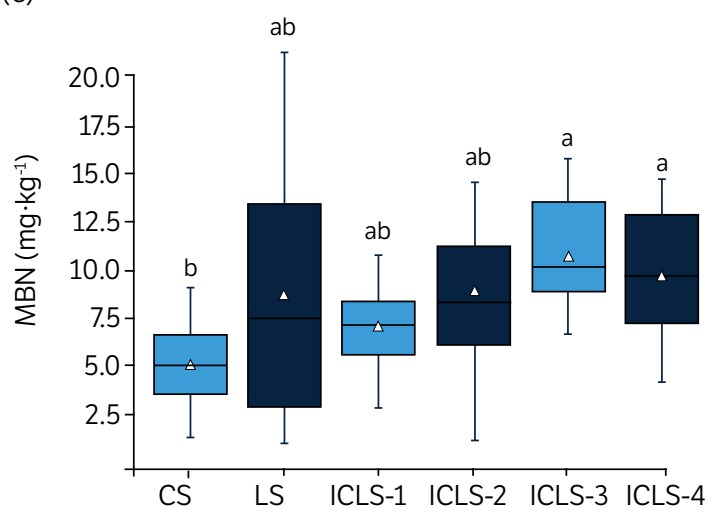

(e)

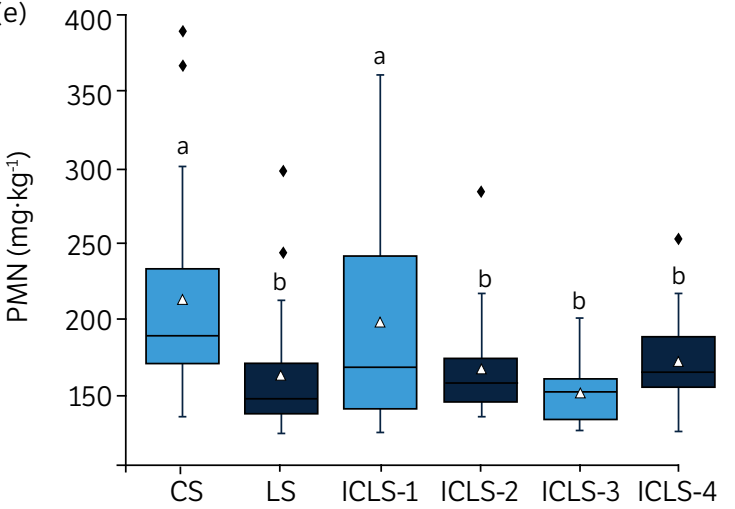

(b)

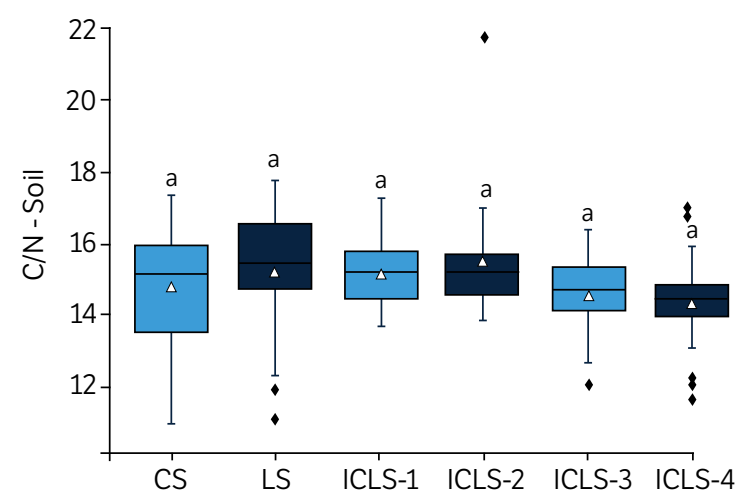

(d)

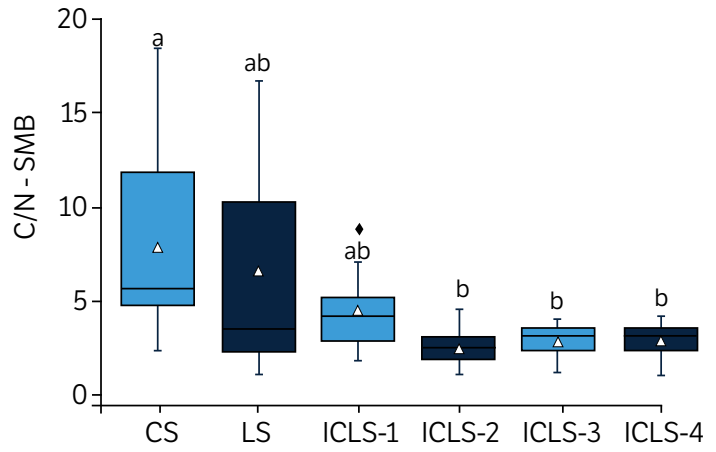

(f)

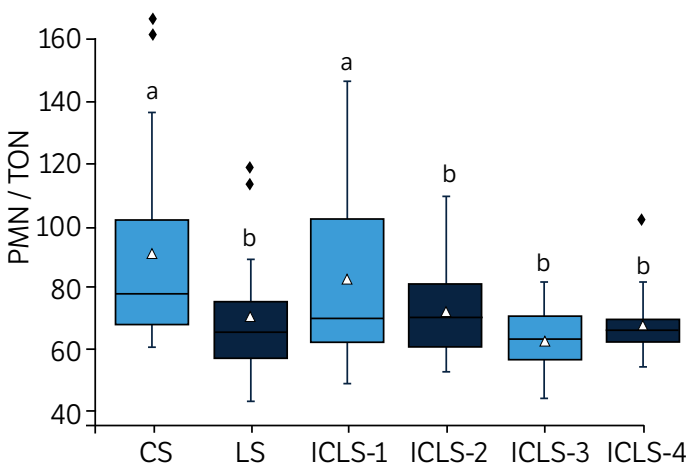

Figure 3. Nitrogen indicators of soil quality as a function of management system*.

TON: total organic nitrogen; $\mathrm{C} / \mathrm{N}$ - Soil: $\mathrm{C} / \mathrm{N}$ ratio of the soil; $\mathrm{MBN}$ : soil microbial biomass nitrogen; $\mathrm{C} / \mathrm{N}$ - SMB: $\mathrm{C} / \mathrm{N}$ ratio of the soil microbial biomass; PMN: potentially mineralizable nitrogen; CS: crop monoculture system; LS: livestock pasture monoculture system; ICLS-1: maize and marandu palisadegrass sown simultaneously, without herbicide; ICLS-2: maize and marandu palisadegrass sown simultaneously, with herbicide; ICLS-3: maize and marandu palisadegrass in lagged sowing; ICLS-4: maize and marandu palisadegrass sown simultaneously in maize rows and inter-rows, with herbicide; - (internal): the second quartile or median; : : the first and third quartiles; T and $\mathrm{I}$ : third and first quartiles up to the upper and lower limits; $\Delta:$ values of the means; : maximum and minimum values; *means followed by similar letters do not differ according to the Tukey’s test at a $5 \%$ probability level.

Both $\mathrm{N}$ and C/N-SMB were greater in ICLS-1, ICLS-2, and ICLS-4, especially in March (Table 4). It is noteworthy that in this experiment this period occurred soon after an increase in the stocking rate in these treatments, reaching 8 AU ha-1, and also after an intense rainy period, with high light intensity and elevated temperatures (Fig. 1). The C/N-SMB suffered a $76 \%$ decrease in the CS and 61\% in the LS during March, in comparison to system ICLS-3. 
Unlike ICLS, the SMB quality was not maintained throughout the year in conventional systems (Table 4), displaying an increase in the CS during January and a decrease in the LS in this period. The most likely explanation is that a specific and unique microbial community colonizes each of these different systems. These communities are adapting to a combination of different $\mathrm{C}$ inputs, and changes in humidity and temperature conditions during the cropping cycle (Ramírez et al. 2020). In this study, these results indicate that this decomposition process is initiated only when the microbial biomass encounters adequate conditions to do so during the seasonal variability, such as the increased precipitation experienced in January (Fig. 1).

There are several possible sources of seasonal variation in soil C and $\mathrm{N}$ in this study. One is the short-lived C pool, generally considered to include particulate organic matter, labile forms, microbial biomass, root exudates, and animal excreta (Wuest 2014; Rakkar et al. 2017). One of the main conclusions of this study is that soil quality indicators can vary with sampling time, with some indicator values showing a large variability between sampling dates. Therefore, because of this variability in soil quality indicators observed between sampling dates, it is advisable that farmers and producers establish a standard sampling time and sample consistently during the same period each year. Sampling at different times of the year will increase the variability of the indicators and reduce the tracking of changes between years. Standard sampling procedures are important because applying fertilizer without understanding the interactions of climate conditions, organics input, and microorganisms in the soil often leads to a cycle of soil degradation that can have a significant effect on long-term productivity and the environment (Omer et al. 2018; Bongiorno et al. 2019; Ramírez et al. 2020).

The interaction between plant and animal residues may have led to a greater C/N-SMB in the first soil layer, subsequently affecting the second layer (Table 4). The sowing technique using nicosulfuron (ICLS-2) demonstrated an effect on SMB, but it did not influence maize productivity. The results of productivity for maize and livestock that were part of this research can be consulted in Mendonça et al. (2020). The investigation found that the intercropping sowing techniques used in the establishment of the ICLS did not affect corn productivity. However, the authors observed significant differences for animal production. The final average weight was 431, 456, 436, $448 \mathrm{e}$ $452 \mathrm{~kg} /$ animal and gain per day was $0.22,0.78,0.82,0.72$ e $0.98 \mathrm{~kg} /$ animal/day, for LS, ICLS-1, ICLS-2, ICLS3 e ICLS- 4 , respectively. Therefore, possibly the differences found in animal production results were a consequence of the inclusion of pastures provided by the sowing techniques used. However, the largest gains per day were observed in ICLS-2 and ICLS-4, which received sub-doses of nicosulfuron to control grass growth; this pasture possibly recovered from the early herbicide application and was able to provide forage biomass that likely influenced the weight of these animals during the seasonal cycle.

\section{Principal component analysis}

To test the influence of seasonal variability on the soil quality indicators, we used three principal components; these principal components (PC1, PC2, and PC3) explained 28.970, 26.344 and 16.496\%, respectively, of the total variance of the co-variance matrix (Table 5). Thus, together, the first three principal components explained $71.81 \%$ of the total variance (Fig. 4).

The greatest correlation in PC1 were with LC and CMI, representing an index of C lability. In the PC2 vs. PC3, the load of variables and the vector directions of TON and C/N-soil (Fig. 4b) and the low correlation and vectorial direction of the PMN and MBC (Fig. 4a) suggest that these soil indicators are not sensitive to systems during the seasonal variability.

In this PC, the load of variables and the vector directions of LC and CMI shown in Table 5 and Fig. 4 suggests that these soil indicators were more sensitive and efficient to verify soil quality changes in the systems in the short term. Furthermore, a positive correlation of TOC with LC, CMI and MBN (Fig. 4b) indicates that the $\mathrm{C}$ stock in the soil is strongly correlated with labile soil fractions and microbial biomass containing nitrogen-rich cells. However, although the LC indicator presents a significant difference only for the livestock treatment in relation to others (Fig. 2c), its use can be suggested because it allows a rapid soil analysis at low cost, considering that the only supplies needed for it are potassium permanganate and a spectrophotometer (Culman et al. 2012; Duval et al. 2018; Bongiorno et al. 2019). 
Table 5. Eigenvalues, variance percentage and cumulative variance percentage of each principal component (PC1 to PC9), and correlation ( $r$ ) between original variables and principal components. Important correlations coefficient $\geq 0.50^{*}$.

\begin{tabular}{|c|c|c|c|}
\hline Principal Components & Eigenvalue & Percentage of variance & $\begin{array}{c}\text { Cumulative variance } \\
\text { percentage }\end{array}$ \\
\hline PC1 & 2.607 & 28.970 & 28.970 \\
\hline PC2 & 2.371 & 26.344 & 55.315 \\
\hline PC3 & 1.485 & 16.496 & 71.810 \\
\hline PC4 & 1.101 & 12.239 & 84.049 \\
\hline PC5 & 0.747 & 8.304 & 92.353 \\
\hline PC6 & 0.466 & 5.181 & 97.534 \\
\hline PC7 & 0.203 & 2.259 & 99.793 \\
\hline PC8 & 0.015 & 0.165 & 99.957 \\
\hline PC9 & 0.004 & 0.043 & 100.000 \\
\hline Variable & PC1 & PC2 & PC3 \\
\hline TOC & 0.20 & 0.27 & -0.13 \\
\hline TON & 0.31 & -0.29 & -0.58 \\
\hline LC & 0.53 & 0.28 & 0.01 \\
\hline MBC & 0.00 & -0.46 & 0.23 \\
\hline PMN & -0.25 & -0.14 & 0.01 \\
\hline MBN & -0.36 & 0.26 & -0.46 \\
\hline CMI & 0.50 & 0.32 & 0.03 \\
\hline $\mathrm{C} / \mathrm{N}$-Soil & -0.17 & 0.44 & 0.52 \\
\hline $\mathrm{C} / \mathrm{N}-\mathrm{SMB}$ & 0.33 & -0.41 & 0.34 \\
\hline
\end{tabular}

*Principal components in bold were chosen according to the Kaiser criterion (1960); TOC: total organic carbon; TON: total organic nitrogen; LC: labile carbon; MBC: soil microbial biomass carbon; PMN: potentially mineralizable nitrogen; $\mathrm{MBN}$ : soil microbial biomass nitrogen; $\mathrm{CMI}$ : carbon management index; $\mathrm{C} / \mathrm{N}-\mathrm{Soil}$ : $\mathrm{C} / \mathrm{N}$ ratio of the soil; $\mathrm{C} / \mathrm{N}-\mathrm{SMB}: \mathrm{C} / \mathrm{N}$ ratio of the soil microbial biomass.

(a)

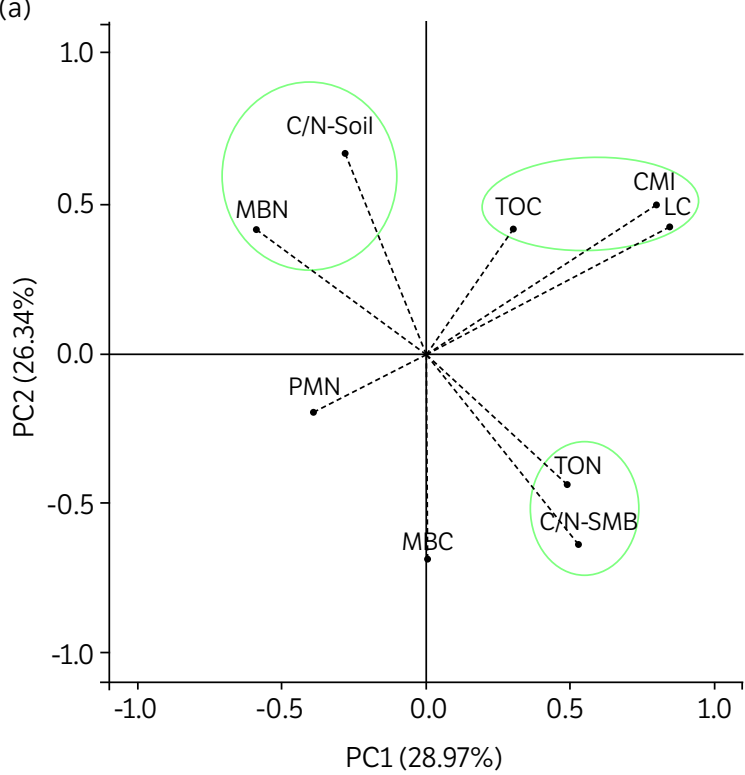

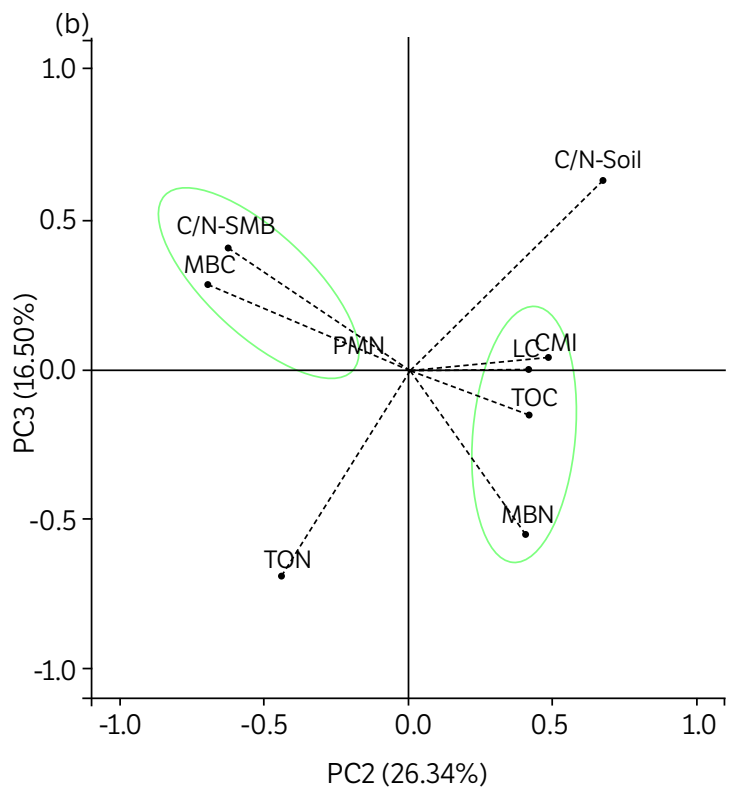

Figure 4. Bi-dimensional plot of (A) PC1 vs. PC2 and (B) PC2 vs. PC3 for soil indicators.

TOC: total organic carbon; TON: total organic nitrogen; LC: labile carbon; MBC: soil microbial biomass carbon; PMN: potentially mineralizable nitrogen; MBN: soil microbial biomass nitrogen; $\mathrm{CMI}$ : carbon management index; $\mathrm{C} / \mathrm{N}$ - Soil: $\mathrm{C} / \mathrm{N}$ ratio of the soil; $\mathrm{C} / \mathrm{N}-\mathrm{SMB}: \mathrm{C} / \mathrm{N}$ ratio of the soil microbial biomass. 


\section{CONCLUSION}

The sowing of maize and marandu palisadegrass with the presence of grazing animals caused short-term changes in soil indicator responses. The best soil quality indicator results were found in ICLS-1 (maize plus marandu palisadegrass sown simultaneously) and ICLS-4 (maize plus marandu palisadegrass sown in maize rows and inter-rows plus the herbicide nicosulfuron). The LC and CMI were more sensitive and efficient indicators for verifying soil quality changes in the systems in the short term during the seasonal variability. However, the soil quality indicator of PMN can also provide positive insights on changes in soil quality as affected by seasonal variability. The results show that there is large variability in these soil indicators during the annual cycle. Therefore, further studies are needed to better understand how these soil quality indicators are affected by seasonal variability, which can help elucidate the mechanisms for improving nutrient dynamics and crop yield stability over time and thus provide information for selecting sowing arrangements that improve the integrated crop-livestock systems.

\section{AUTHORS' CONTRIBUTION}

Conceptualization: Simili, F. F.; Methodology: Simili, F. F. and Cruz, M. C. P.; Investigation: Maia, N. J. C., Menegatto, L. S., Augusto, J. G., Mendonça, G. G., Terçariol, M. C.; Writing - Original Draft: Maia, N. J. C. and Simili, F. F., Cruz, M. C. P.; Writing - Review and Editing: Maia, N. J. C., Simili, F. F., Cruz, M. C. P., Oliveira, J. G., Dubeux Junior, J. C. B.; Funding Acquisition: Simili, F. F.; Supervision: Simili, F. F.; Formal Analysis: Maia, N. J. C.

\section{DATA AVAILABILITY STATEMENT}

All dataset was generated and analyzed in the current study.

\section{FUNDING}

Fundação de Amparo à Pesquisa do Estado de São Paulo

https://doi.org/10.13039/501100001807

Grants No: 2014/24514-6, 2017/50339-5

Coordenação de Aperfeiçoamento de Pessoal de Nível Superior

https://doi.org/10.13039/501100002322

Finance Code 001.

\section{REFERENCES}

Blair, G. J., Lefroy, R. D. B. and Lisle, L. (1995). Soil carbon fractions based on their degree of oxidation, and the development of a carbon management index for agricultural systems. Australian Journal of Agricultural Research, 46, 1459-1466. https://doi.org/10.1071/AR9951459 Bockheim, J. G., Gennadiyev, A. N., Hartemink, A. E. and Brevik, E. C. (2014). Soil-forming factors and Soil Taxonomy. Geoderma, 226227, 231-237. https://doi.org/10.1016/j.geoderma.2014.02.016 
Bongiorno, G., Bünemann, E. K., Oguejiofor, C. U., Meier, J., Gort, G., Comans, R., Mäder, P., Brussaard, L. and Goede, R. (2019). Sensitivity of labile carbon fractions to tillage and organic matter management and their potential as comprehensive soil quality indicators across pedoclimatic conditions in Europe. Ecological Indicators, 99, 38-50. https://doi.org/10.1016/j.ecolind.2018.12.008

Chi, Y., Shi, H., Zheng, W. and Sun, J. (2017). Multiple gradient effects on spatial distribution of island soil microbial biomass. European Journal of Soil Biology, 83, 65-75. https://doi.org/10.1016/j.ejsobi.2017.10.006

Coser, T. R., Ramos, M. L. G., Figueiredo, C. C., Carvalho, A. M., Cavalcante, E., Moreira, M. K. R., Araújo, P. S. M. and Oliveira, S. A. O. (2016). Soil microbiological properties and available nitrogen for corn in monoculture and intercropped with forage. Pesquisa Agropecuária Brasileira, 51, 1660-1667. https://doi.org/10.1590/S0100-204X2016000900066

Culman, S. W., Snapp, S. S., Freeman, M. A., Schipanski, M. E., Beniston, J., Lal, R., Drinkwater, L. E., Franzluebbers, A. J., Glover, J. D., Grandy, A. S., Lee, J., Six, J., Maul, J. E., Mirksy, S. B., Spargo, J. T. and Wander, M. M. (2012). Permanganate oxidizable carbon reflects a processed soil fraction that is sensitive to management. Soil Science Society of America Journal, 76, 494-504. https://doi.org/10.2136/ sSsaj2011.0286

Dumont, B., Fortun-Lamothe, L., Jouven, M., Thomas, M. and Tichit, M. (2013). Prospects from agroecology and industrial ecology for animal production in the 21st century. Animal, 7,1028-1043. https://doi.org/10.1017/S1751731112002418

Duval, M. E., Galantini, J. A., Martínez, J. M. and Limbozzi, F. (2018). Labile soil organic carbon for assessing soil quality: influence of management practices and edaphic conditions. Catena, 171, 316-326. https://doi.org/10.1016/j.catena.2018.07.023

Fierer, N., Grandy, A. S., Six, J. and Paul, E. A. (2009). Searching for unifying principles in soil ecology. Soil Biology and Biochemistry, 41, 2249-2256. https://doi.org/10.1016/j.soilbio.2009.06.009

Freitas, F. C. L., Santos, M. V., Machado, A. F. L., Ferreira, L. R., Freitas, M. A. M. and Silva, M. G. O. (2008). Behavior of corn cultivars intercropped with Brachiaria brizantha in the presence and absence of sprayed for am sulfuron + iodosulfuron-methyl. Planta Daninha, 26, 215-221. https://doi.org/10.1590/S0100-83582008000100022

Freitas, M. A. M., Silva, D. V., Guimarães, F. R., Leal, P. L., Moreira, F. M. S., Silva, A. A. and Souza, M. F. (2018). Biological attributes of soil cultivated with corn intercropped with Urochloa brizantha in different plant arrangements with and without herbicide application. Agriculture, Ecosystems \& Environment, 254, 35-40. https://doi.org/10.1016/j.agee.2017.10.026

Galindo, F. S., Delate, K., Heins, B., Phillips, H., Smith, A. and Pagliari, P. H. (2020). Cropping System and Rotational Grazing Effects on Soil Fertility and Enzymatic Activity in an Integrated Organic Crop-Livestock System. Agronomy, 10, 803. https://doi.org/10.3390/ agronomy10060803

Ghimire, R., Thapa, V. R., Cano, A. and Acosta-Martinez, V. (2019). Soil organic matter and microbial community responses to semiarid croplands and grasslands management. Applied Soil Ecology, 141, 30-37. https://doi.org/10.1016/j.apsoil.2019.05.002

Jakelaitis, A., Silva, A. F., Silva, A. A., Ferreira, L. R., Freitas, F. C. L. and Vivian, R. (2005). Influência de herbicidas e de sistemas de semeadura de Brachiaria brizantha consorciada com milho. Planta Daninha, 23, 59-67. https://doi.org/10.1590/S0100-83582005000100008

Kaiser, H. F. (1960). The application of electronic computers to factor analysis. Educational and Psychological Measurement, 20, 141151. https://doi.org/10.1177/001316446002000116

Karpouzas, D. G., Kandeler, E., Bru, D., Friedel, I., Auer, Y., Kramer, S., Vasileiadis, S., Petric, I., Udikovic-Kolic, N., Djuric. S. and Martin-Laurent, F. (2014a). A tiered assessment approach based on standardized methods to estimate the impact of nicosulfuron on the abundance and function of the soil microbial community. Soil Biology and Biochemistry, 75, 282-291. https://doi.org/10.1016/j.soilbio.2014.04.022

Karpouzas, D. G., Papadopoulou, E., Ipsilantis, I., Friedel, I., Petric, I., Udikovic-Kolic, N., Djuric, S., Kandeler, E., Menkissoglu-Spiroudi, U. and Martin-Laurent, F. (2014b). Effects of nicosulfuron on the abundance and diversity of arbuscular mycorrhizal fungi used as indicators of pesticide soil microbial toxicity. Ecological Indicators, 39, 44-53. https://doi.org/10.1016/j.ecolind.2013.12.004 
Kluthcouski, J., and Aidar, H. (2003). Implantação, condução e resultados obtidos com o Sistema Santa Fé. In: Kluthcouski, J., Stone, L. F. and Aidar, H. (Eds.). Integração Lavoura-pecuária (p. 408-441). Santo Antônio de Goiás: Embrapa Arroz e Feijão.

Loss, A., Pereira, L. M. G., Perin, A., Beutler, S. J. and Anjos, L. H. C. (2013). Oxidizable carbon and humic substances in rotation systems with brachiaria/livestock and pearl millet/no livestock in the Brazilian Cerrado. Spanish Journal of Agricultural Research, 11, 217-231. https://doi.org/10.5424/sjar/2013111-3416

Mateus, G. P., Borghi, E., Marques, R. R., Villas Boas, R. L. and Crusciol, C. A. (2007). Sources and time of contact of mineral fertilizer with brachiaria brizantha seeds as related with germination. Revista Brasileira de Ciência do Solo, 31, 77-183. http://dx.doi.org/10.1590/ S0100-06832007000100018

Mendonça, G. G., Simili, F. F., Augusto, J. G., Bonacim, P. M., Menegatto, L. S. and Gameiro, A. H. (2020). Economic gains from croplivestock integration in relation to conventional systems. Revista Brasileira de Zootecnia, 49, 1-11. https://doi.org/10.37496/rbz4920190029

Monz, C. A., Reuss, D. E., and Elliott, E. T. (1991). Soil microbial biomass carbon and nitrogen estimates using $2450 \mathrm{MHz}$ microwave irradiation or chloroform fumigation followed by direct extraction. Agriculture, Ecosystems \& Environment, 34, 55-63. https://doi. org/10.1016/0167-8809(91)90093-D

Omer, M., Idowu, O. J., Ulery, A. L., VanLeeuwen, D. and Guldan, S. J. (2018). Seasonal changes of soil quality indicators in selected arid cropping systems. Agriculture, 8, 124. https://doi.org/10.3390/agriculture8080124

Osterholz, W. R., Rinot, O., Shaviv, A., Linker, R., Liebman, M., Sanford, G., Strock, J. and Castellano, M. J. (2017). Predicting gross nitrogen mineralization and potentially mineralizable nitrogen using soil organic matter properties. Soil Science Society of America Journal, 81 , 1115-1126. https://doi.org/10.2136/sssaj2017.02.0055

Raij, B. V., Andrade, J. C., Cantarella, H. and Quaggio, J. A. (2001). Análise química para avaliação da fertilidade de solos tropicais. Campinas: Instituto Agronômico de Campinas.

Rakkar, M. K., Blanco-Canqui, H., Drijber, R. A., Drewnoski, M. E., MacDonald, J. C. and Klopfenstein, T. (2017). Impacts of cattle grazing of corn residues on soil properties after 16 years. Soil Science Society of America Journal, 81, 414-424. https://doi.org/10.2136/sssaj2016.07.0227

Ramírez, P. B., Fuentes-Alburquenque, S., Díez, B., Vargas, I. and Bonilla, C. A. (2020). Soil microbial community responses to labile organic carbon fractions in relation to soil type and land use along a climate gradient. Soil Biology and Biochemistry, 141, 107692. https:// doi.org/10.1016/j.soilbio.2019.107692

Roberts, T. L., Norman, R. J., Slaton, N. A., Wilson, C. E., Ross, W. J. and Bushong, J. T. (2009). Direct steam distillation as an alternative to the Illinois soil nitrogen test. Soil Science Society of America Journal, 73, 1268-1275. https://doi.org/10.2136/sssaj2008.0165

Santos, H. G., Jacomine, P. K. T., Anjos, L. H. C., Oliveira, V. A., Lumbreras, J. F., Coelho, M. R., Almeida, J. A., Araujo Filho, J. C., Oliveira, J. B. and Cunha, T. J. F. (2018). Sistema brasileiro de classificação de solos. Brasília: Embrapa.

Silva, E. E., Azevedo, P. H. S., De-Polli, H. (2007). Determinação do nitrogênio da biomassa microbiana do solo (BMS-N). Comunicado técnico, 96. Seropédica: Embrapa.

Silva, F. D., Amado, T. J. C., Ferreira, A. O., Assmann, J. M., Anghinoni, I., and Carvalho, P. C. F. (2014). Soil carbon indices as affected by 10 years of integrated crop-livestock production with different pasture grazing intensities in Southern Brazil. Agriculture, Ecosystems \& Environment, 190, 60-69. https://doi.org/10.1016/j.agee.2013.12.005

Strickland, M. S., Thomason, W. E., Avera, B., Franklin, J., Minick, K., Yamada, S. and Badgley, B. D. (2019). Short Term effects of cover crops on soil microbial characteristics and biogeochemical processes across actively managed farms. Agrosystems, Geosciences \& Environment, 2, 1-9. https://doi.org/10.2134/age2018.12.0064 
Viaud, V., Santillàn-Carvantes, P., Akkal-Corfini, N., Guillou, C. L., Prévost-Bouré, N. C., Ranjard, L. and Menasseri-Aubry, S. (2018). Landscape-scale analysis of cropping system effects on soil quality in a context of crop-livestock farming. Agriculture, Ecosystems \& Environment, 265, 166-177. https://doi.org/10.1016/j.agee.2018.06.018

Walkley, A., Black, I. A. and Armstrong, I. (1934). An examination of the Degtjareff method for determining soil organic matter, and a proposed modification of the chromic soil titration method. Soil Science, 37, 22-38.

Wang, F., Weil, R. R. and Nan, X. (2017). Total and permanganate-oxidizable organic carbon in the corn rooting zone of US Coastal Plain soils as affected by forage radish cover crops and N fertilizer. Soil and Tillage Research, 65, 247-257. https://doi.org/10.1016/j.still.2016.08.022

Weil, R. R., Islam, K. R., Stine, M. A., Gruver, J. B. and Samson-Liebig, S. E. (2003). Estimating active carbon for soil quality assessment: a simplified method for laboratory and field use. America Journal of Alternative Agriculture, 18, 3-17. https://doi.org/10.1079/AJAA200228

Wuest, S. (2014). Seasonal variation in soil organic carbon. Soil Science Society of America Journal, 78, 1442-1447. https://doi.org/10.2136/ sssaj2013.10.0447 